\title{
Lowering of Government Supervision Impact on Weight of Criminal Legal Rules to Real Mineral and Coal Mining Business in Indonesia
}

\author{
Bambang Ery anto Hermawan \\ Doctoral Program of Law Science \\ Brawijay a University \\ Malang, Indonesia \\ b_e_hermawan@yahoo.co.id
}

\author{
Sonder John Wendhy \\ Doctoral Program of Law Science \\ Brawijay a University \\ Malang, Indonesia \\ sonder91@gmail.com
}

\begin{abstract}
In the implementation of mining business, the government is authorized in terms of guidance and supervision in this case by the Minister of Energy and Mineral Resources. As well as criminal sanctions stipulated in Law No. 4 of 2009 is still relatively low. Where in this case experiencing an inaccurate reporting of supervision from the government then it is metamorphosed sanctions penal ties are still weak against the mining business actors. Any reporting submitted by the government and actions violated by the mining business actors may also be criminalized. If this is ignored by criminal sanctions, all ecosystems in the environment will be damaged and have a major impact on communities in the vicinity of the mine site. This loss affects economic growth and environmental sustainability of ecosystems in Indonesia.
\end{abstract}

\section{Keywords-Weak Oversight, Weak Criminal Sanctions}

\section{INTRODUCTION}

In the country of Indonesia where natural wealth and crops are a gift from God Almighty, One of the minerals and mineral mining. However, in the case of mine product management, it may reap the problems particularly related to mining permits that may have legal implications for civil and criminal law enforcement. All characteristics of mineral and coal mining business activities. It is necessary to ensure the management, supervision of mining for legal certainty in the world of mineral and coal mining. Where Law No. 4 of 2009 on Mineral and Coal Mining (Minerba Act), replaces Law Number 11 Year 1967 regarding Provisions on Basic Provisions of Mining (Law No.11 Year 1967).

The fundamental change that occurs is the change of the contract system of work and the agreement into a licensing system, so that the Government is no longer in a position parallel to the business actors and the licensing party to the business actors in the mineral and coal mining industry. The presence of Law No. 4 of 2009 on Mineral and Coal Mining (Minerba Law), the Minerba Law reaps weaknesses against legal sanctions, especially criminal sanctions that are still considered weak. If the application of criminal sanction is affirmed in criminal prosecution, it is possible that business actors in the minerba field will be more careful.

Systematics in Law Nu mber 4 Year 2009 (Minerba Act) are as follows:

1. General Provisions;
2. Principles and Objectives;

3. Mineral and coal control;

4. Authority of mineral and coal mining management;

5. Mining areas;

6. Mining Business;

7. Mining Business License

8. Licensing of Mining Business License;

9. People's Mining Permit;

10. Special Mining Business License;

11. Special Mining Business Licensing Requirements;

12. Mining Data;

13. Rights and Handicrafts;

14. Temporary Termination of Activities of Mining Business License and Special Mining Business License;

15. The ending of Mining Business License and Special Mining Business License;

16. Mining Services Business;

17. State and Regional Revenue;

18. Use of Toll for Mining Business Activities;

19. Community Development, Monitoring and Protection;

20. Research and Development and Education and Training;

21. Investigation;

22. Adminis trative Sanctions

23. Criminal Provisions;

24. Other Provisions;

25. Transitional Provisions;

26. Closing Provisions..

\section{DISCUSSION ISSUES}

A. Weak License of Monitoring of Mining License Potentially Can Trigger Violation of Crime

Mal-administration in granting mining permits by authorized officers is highly potential for criminal offenses. This act has the potential to lead to abuse of authority. This admin istrative maladministration can be analyzed through the character of authority and legitimacy of government acts. Nevertheless, all acts of abuse of authority may be liable, unless there is a financial loss to the state. A government official who does not have the authority to engage in a particular legal act can't be declared as a perpetrator of abuse of authority, if he has undertaken a state administrative 
action or decision which is not within the scope of his / her authority.

There is no authority, then there is no abuse of authority. In the management and supervision of mining, the use of authority has a close relationship with the policy. The granting of mining permits is the decision of the competent authority. The nature of this decision can be assessed through the character of distribution authority. The functions and authorities of the regional government as stipulated in Article 18, Article 18A, Article 18B of the 1945 Constitution, and Article 6, Article 7 and Article 8 of Law No.4 of 2009, and Article 10 (2), 13 (b), and Article 25 (g) of Law no. 32 In 2004. On the other hand, Laica Marzuki's. ${ }^{1}$ statement in commenting on the beleidregel policy that can't be brought before the judge or can't be punished, because the policy is not part of the legislation. In essence the "beleidsregel" policy is part of the government's freedom of action discretionary power or commonly known as freies ermessen. When it is proven that an official-misuses his or her policy of abuse of power, there will be two kinds depending on the classification of offenses and liability covering the responsibilities of office and personal responsibility.

However, according to D. Hazewinkel-Suringa in Loebby Loqman, ${ }^{2}$ the thought contained in the formula is also found in Montesquieu's teachings on the doctrine of separation of powers, not the judge who mentions what can be punished, the legislator creates the law. Lawmakers not only set the norm but must also be announced as norms before the action. The first manifestation in the Constitution of America in 1783 and subsequently and later in Article 8 Declaration desdroits de l'homme et du citoyen in 1789. Finally appears in Article 4 of the Penal Code and WvS Netherlands which then descended into the Indonesian Penal Code, and the Criminal Code Belgium in Section 2. As already noted above, the Legality Principles of the Indonesian Penal Code (orig inating from WvS Ned.) Are in fact the rules set forth in the Declaration Des Droits DeL'Homme Et Du Citoy of 1789, which reads:

"No one shall be punished other than by the force of a pre-existing law".

According to Djojodigoeno in Andi Hamzah ${ }^{3}$ the term norm is commonly used although there are other writings that replace the term with the rules. The norm has values in a series of abstract conceptions that live among human groups as a provision that must be obeyed by everyone in the social life of the community, and has the task of ensuring lawful order in society. Legislators, especially of the legislator (wetgiver) can set the norm, so that most of the norms can be found in the law. The form of norm in the law or other rules is basically a prohibited act or a necessity to do (verboden of

1 Philipus.M Hadjon, Paul Effendie Lotulung, H.M. Laica.Marzuki, Tatiek.Sri Djatmiati, I Gusti Ngurah Wairocana, Administrative and Good Governance Law, Jakarta: Trisakti University, 2010, p.56.

2 Loebby Loqman, "Development of Legality Principles in Indonesian Penal Code", Paper Presented at Seminar on National Criminal Law Principles Organized By: National Legal Development Board Ministry of Justice and Human Rights, in collaboration with Diponegoro University Faculty of Law, Semarang, Puri Suite Hotel Ciputra, Semarang, 26-27 April 2004. In the explanation of D. HazewinkelSuringa, Inleiding tot de studie van het Nederlandse Strafrecht, 1983, p. 380.

3 Andi Hamzah, Principles of Criminal Law, Jakarta: P.T Rinaka Cipta, 1994. P.9; Oheo K Haris: Criminal Legal Aspects p.356. geboden). Sanctions contain a nucleus in the form of a criminal threat (strafbedreiging), and have the duty so that the norms that have been established can be obeyed and as a result of law for violation of the norm.

Now the service of 18 licenses in this minerba, 11 licenses have been transferred to One Stop Integrated Service (PTSP) at the Investment Coordinating Board (BKPM), namely:

1. Exploration Mining Business License;

2. Mining Business Operation License and its Renewal;

3. Termination of Mining Business License under Refunds;

4. Mining Production Operating License for transport and sale and renewal;

5. Mining Business Operating License Special production of processing and / or refining and extension;

6. Temporary permit to carry out transportation and sales;

7. Mining Production Operation License for sale;

8. License of Processing and / or Refining Principles;

9. Mining Business License and Renewal;

10. Change of Status of Domestic Investment Company into Foreign Investment Company;

11. Change of status of Foreign Investment Company into a Domestic Investment Company.

In the EBTKE subsector, after most licenses have been transferred to BKPM, only 3 licenses and 7 non-licensing types are still handled by Directorate General of New Renewable Energy and Energy Conservation (Ditjen EBTKE), including:

Permissions:

1. License to Implement Minimum Energy Performance Standards (SKEM) and Inclusion of Energy Efficient Label Labels for Air Conditioning Equipment (AC);

2. Label Affixing Energy Saving Label on Swab-ballast Lamp; and

3. Business License of Biodiesel Fuel Business (Biofuel).

Non-Licensing:

1. Issuance of certificates of feasibility of use of geothermal equipment;

2. Issuance of certificate of feasibility of geothermal installation;

3. Recommendation of foreign worker usage plan;

4. Recommendation for permission to use foreign workers;

5. Recommendation of geothermal goods import plan;

6. SKT Service of energy conservation support (ESCO); and

7. Recommendation of export and import of biofuels (BBN).

B. The Inadequate Supervision of Officials Against Mining Businessmen Potentially Can Trigger Violation of Criminal Acts

Supervision is essentially aimed at preventing errors and pointing out the right way and purpose. By applying the 
principle of coordination, the nature of supervision can be optimal and can be a solution in realizing a balance, namely the management of mines that are environmentally sound and thus can realize the implementation of law enforcement in mining business. It is better to have the supervision of the community for social supervision, in contrast to the supervision made by the officials responsible for the implementation of the mining business. Through the supervision of the community as control of the control to foster awareness within each person the importance of environmental protection and environmental management, in which the surrounding communities are directly affected by the mining business.

The district / municipality government is one of the parties with the authority to supervise the implementation of "good mining practices" in a mineral mining business in its mining area and the responsible Agency is the Department of Energy and Mineral Resources (ESDM), this is based on Article 8 Minerba Act. Supervision of the implementation of "good mining practice" conducted on the aspects of the provisions of safety and health of mining work; reclamation and post mining activities, mineral and coal resources conservation efforts, mine waste management from a mining business activity in solid, liquid, or gas form to meet environmental quality standards before being released to environmental media by reviewing the Mining Business License (IUP), Plan Work and Cost Report (RKAB) and Quarterly Report include:

1. Technical Mining;

2. Marketing;

3. Finance;

4. Minerba Data Management; Mining Exploration;

5. Occupational Safety and Health Mining;

6. Safety of Mining Operations;

7. Environmental Management, Reclamation and Postmining;

8. Utilization of Goods, Services, Technology, and Capabilities;

9. Engineering and Design of Domestic Affairs;

10. Development of Mining Technical Workers;

11. Local Community Development and Empowerment;

12. Mastery, Development and Application of Mining Technology;

13. Other Activities in the Field of Mining Business Activities Concerning the Public Interest;

14. Management of Mining Business License (IUP) or Special Mining Business License (IUPK);

15. Number, Type, and Quality of Mining Business Results.

With the weak supervision of government agencies that have the potential to occur the implementation of criminal offenses is not effective with the consequences of business actors not implementing "good mining practice", which where the mining business actor sometimes becomes an opportunity to make a deviation against some rules that have been determined in Law Number 4 Year 2009 (Minerba Act). For criminal prosecution and penalties in the Minerba Act are still relatively small and not comparable with what has been done exploration of mining in this mining business in the interests of business in corporation, thus ignoring the "good mining practice".
Where a criminal offense is an act committed under certain circumstances and circumstances by law is prohibited, which in consequence has occurred may result in corporal punishment and / or morals for the perpetrator. Whereas Mining is part or all of the phases of activities in the framework of research, management and exploitation of minerals or coal covering general investigation, exploration, feasibility study, construction, mining, processing and refining, transportation and sales, and post-mining activities. Whereas the criminal act of mining is an act that is prohibited by regulations-imposed sanctions for the perpetrators of the act, in order to protect the activities and efforts of mineral mining and coal

For the existence of criminal responsibility, it must be clear in advance who can be accounted for. This means that it should be noted who is declared a maker for a particular offense. This issue involves the subject of criminal offenses that are generally formulated by the law makers for the criminal offenses concerned.

The expansion of criminal law subjects in Law Number 4 Year 2009 on Mineral and Coal Mining can be found its juridical basis, namely the provision of the Criminal Code (Penal Code) in Article 103. When examined far, it can be said corporation as the subject of criminal law in Law Number 4 Year 2009 Concerning Mineral and Coal Mining which can be accounted for by the Board and its corporation based on Article 163 paragraph (1). It is quite unfortunate too that the Law always refers to every person as its legal subject namely Articles 158, 160, 161, 162 and Article 165. However, it is not followed by the definition of each person.

In a special law outside the Criminal Code, the subject of criminal offenses is extended to corporations but some are not accompanied by the provisions of corporate criminal liability. In Law No. 4 of 2009 on Mineral and Coal Mining, there is no article in the law that regulates how or when the corporation can be criminally accounted for.

The placement of a corporation as a subject of criminal law is that the offender of the corporation is incorporated as a funcionneel daderschap, since corporations in the modern world have an important role in economic life that has many functions, such as employers, producers, pricing, foreign exchange users and others -other.

The view of the corporate criminal liability system as a subject of criminal law, namely:

1. The manager of the corporation as the maker, then the board is responsible;

2. The corporation as the maker, then the board is responsible; and

3. Corporations as makers and those responsible.

Based on these descriptions and in relation to criminal liability by corporations in the mining sector, it will try to examine the criminal liability of corporations in the field of mining through its national legislation established in Indonesia, namely Law No. 4 of 2009 on Mining Minerals and Coal, in Law No. 4 of 2009 on Mineral and Coal Mining, has regulated the corporate criminal liability in the field of mining.

In Government Regulation No. 23/2010 concerning the Implementation of Mineral and Coal Mining Business Activities, business entities may be business entities, private 
enterprises, State Owned Enterprises (BUMN) and Regional Owned Enterprises (BUMD), while individuals may be individuals, firms or corporate partners. If more closely observed in the business entity in the formulation of Law No. 4 of 2009 is only directed to the business entity only is private entities in the form of limited liability company (Law Number 40 Year 2007), BUMN and BUMD. because Law No. 4 of 2009 is a Lex specialist, a mining company in the form of a cooperative (based on Law Nu mber 25 of 1992 and its deed of establishment approved by the Minister of Transmigration and Cooperation) does not appear to be included in the definition of a legal entity in Law Nu mber 4 The year 2009 .

If a criminal act in the field of mining is carried out by a legal entity, then that which can be prosecuted is a legal entity, but the sentence imposed by a judge in addition to imprisonment, as well as penalties against the caretaker. In addition to the legal entity is sentenced in the form of a fine penalty with a weighting plus $1 / 3$ (one third) of the maximum provision of a fine penalty imposed. Then the judge may also impose additional penalties on a legal entity in the form of revocation of business license and / or revocation of its legal entity status.

The shortcomings contained in Law Nu mber 4 Year 2009 are not regulating the corporation as a criminal offender as in other laws such as the Aviation, Fisheries, Narcotics Act. Because the corporation's definition includes a group of people, whether incorporated or non-legal entity, if this is regulated in Law Number 4 Year 2009 then all companies established by at least 2 (two) persons, may become the perpetrators of criminal acts in the field mining in violation of the law

In Law No. 4 of 2009 on Mineral and Coal Mining, the articles containing criminal sanctions are provided in Chapter XXIII on "Criminal Provisions", in which there are 8 (eight) articles starting from Article 158 to Article 165. is seen as an admin is trative criminal law. Referring to the contents of the Minerba Act is known there are 3 (three) types of permits) namely IUP, IPR, and IUPK. To obtain the mining permit must meet administrative requirements. From this it is clear that the provisions of Articles 158 to 165 where in essence the provisions of the article as the embodiment of criminal law politics as a tool to enforce administrative legal norms.

In the Criminal Code there are two types of criminal sanctions, namely "Criminal Penalty" and "Additional Criminal Law" which is regulated in Article 10. This also happens in the Minerba Act. Types of criminal sanctions that may be imposed in the form of principal and additional criminal sanctions. Furthermore, when observed the criminal provisions of the Minerba Act using the pattern of cumulative and alternative criminal threats. The Criminal Code is known for minimal public penalty, maximally general and special maximum. Therefore, in determining the severity of the crime, the judge shall be granted the freedom from minimum to maximum as a reasonable reaction from the offense committed by the defendant. The provisions in the Minerba Act also when examined in accordance with the same matters as stipulated in the Criminal Code, thus stated in the articles only contain a special maximum criminal threat, and automatically the general minimu m provisions in the Criminal Code apply to criminal acts as regulated in the Minerba Act
The Minerba Act threatens the very high penalty of penalties against human as well as legal entities but is not accompanied by rules on how the criminal act is carried out and substitution alternative if the fine is not fulfilled. By not regulating how the criminal act is carried out it will affect the active or whether the threat of revenge is threatened.

\section{CONCLUSIONS}

Judging from the above description is still the weakness of supervision in Law Number 4 Year 2009 where the perpetrators of criminal and corporate criminal liability are only directed to the corporation in the broadest sense, the supervision should be done by the central and regional government should first understand:

a. Minerals and coal are non-renewable natural resources that have an important role in fulfilling the livelihood of the people, and provide a real added value to the national economy in an effort to achieve prosperity and welfare of the people, in order to create a balance between the application of criminal or civil law in ecosystemair, water, and soil;

b. Mineral and coal min ing activities containing economic value shall be initiated since the attempt to know the position, area, reserve amount, and geography of the land containing minerals and coal. Once the reserve is found then the process of exploitation (production), transport, and other supporting industries will have a very high economic value so that it will open the business competition within the chain of the industry, it will be a criminal act;

c. Business actors in minerals and coal will tend to maximize the mines in which due to the existence of supervision and the application of criminal and civil penalties due to the rules between the central and local governments are still overlapping, consequently the application of especially the criminal law is sometimes only empty and pepesan ineffective in the absence of oversight, execution and decisive action by the government.

\section{SUGGESTIONS}

The central and local governments should be more responsive to the overlapping problems that occur in the perpetrators of criminal acts and criminal liability by corporations only to the corporation in the broad sense, where due to the weak supervision and legal action due to negligence by the minerals and mining business actors, the central government needs to revise the related criminal penalty rules in Law No. 4 of 2009 on Mineral and Coal Mining, thereby thereby supporting the implementation of preventive legal actions through integrated supervision.

\section{REFERENCES}

[1] Adami Chazawi, Criminal Law Lesson Part 1, Jakarta: PT. Raja Grafindo Persada, 2002;

[2] Andi Hamzah, Principles of Criminal Law, Jakarta: P.T Rinaka Cipta, 1994; Oheo K Haris: Legal Aspect of Criminal, 1994;

[3] ___ Principles of Criminal Law, Jakarta: Rineka Cipta, $1991 ;$

[4] ___ Indonesian Criminal Procedure Code, Revised Edition, Jakarta: Sinar Grafika, 2006; 
[5] Bambang Poernomo, Principles of Criminal Law, Jakarta: Ghalia Indonesia, 1985;

[6] Barda Nawawi Arief, Culmination of Criminal Law Policy, Bandung: PT. Citra Aditya Bhakti, 1996.

[7] __ Some Aspects of Criminal Law Enforcement and Development Policy, Bandung: Citra Aditya Bakti, 1 st Print, 1998;

[8] ___ Kapita Selekta Penal Law on Integrated Criminal Justice System, Diponegoro University Publishing Agency, Semarang, 2006;

[9] ___ Cultivation Bureau of Criminal Law Policy (Development of Preparation of New Criminal Code Concept), Jakarta: Kencana, 2008;

[10] ___ Development of Indonesian Criminal Law Principles, Library Magister Semarang, 2008;

[11] E Utrecht, Criminal Law 1, University of Indonesia, Jakarta, 1956;

[12] Loebby Loqman, "Development of Legality Principles in Indonesian Penal Code", Paper Presented at Seminar on National Criminal Law Principles Organized By: National Legal Development Board Ministry of Justice and Human Rights, in collaboration with Diponegoro University Faculty of Law, Semarang, Puri Suite Hotel
Ciputra, Semarang, 26-27 April 2004. In the explanation of D. Hazewinkel-Suringa, Inleiding tot de studie van het Nederlandse Strafrecht, 1983;

[13] Philipus.M Hadjon, Paul Effendie Lotulung, H.M. Laica.Marzuki, Tatiek.Sri Djatmiati, I Gusti Ngurah Wairocana, Administrative and Good Governance Law, Jakarta: Trisakti University, 2010;M. Young, The Technical Writer's Handbook. Mill Valley, CA: University Science, 1989.

\section{RELATED LAWS AND REGULATIONS IN INDONESIA}

[1] Law Number 11 Year 1967 concerning Mining Basic Regulations (State Gazette Year 1967 Number 22);

[2] Law Number 4 of 2009 concerning Mineral and Coal Mining (Stat ute Book of 2009 No. 4);

[3] Government Regulation Number 22 Year 2010 concerning Mining Areas (State Gazette Year 2010 Number 28);

[4] Government Regulation Number 23 Year 2010 concerning the Implementation of Mineral and Coal Mining Business Activities (State Gazette Year 2010 Number 28). 